\title{
Electronic Work Record in the Digital Economy: Realities and Prospects
}

\author{
Lada A.S. \\ Department of public and private law of Far-East Institute of Management, Branch of RANEPA, 680000, Khabarovsk, \\ Russia \\ ${ }^{*}$ Corresponding author. Email: alexlada@inbox.ru
}

\begin{abstract}
The article examines the history of the formation and development of legislation on labor books in the Russian Federation, analyzes the foreign experience of the formation of similar institutions, and provides judicial practice. Based on the analysis of scientists ' opinions on the need to leave the Institute of labor books in the Russian Federation, the author comes to the conclusion that at present it is impossible to abandon this Institute. In connection with the transition to electronic labor books, the author gives the pros and cons of such a transition and generally agrees with the need for a gradual transition to electronic labor books. Analyzing the legislation on electronic labor books, the author identifies a number of problems related to the content of the electronic labor books, the procedure for maintaining an electronic labor books $\mathrm{k}$ and the procedure for switching to electronic labor books s and suggests appropriate changes to the labor legislation. Keywords: electronic labor books, work experience, job information
\end{abstract}

\section{INTRODUCTION}

Issues of legal regulation of labor books and the transition to electronic labor books concern every employee, since the labor books reflects objective information about the employee's work activity, and it also serves as one of the proofs of work experience.

In Russia, labor books were first introduced by The decree of the Central Executive Committee of June 25, 1919 "on the introduction of labor books in Moscow and Petrograd". Moreover, in some cases, labor books replaced the passport. The employment record included information about earnings, as well as payment of social security and labor protection contributions. In 1926, the labor books were replaced with work lists that all employers were required to keep, and in 1938, the labor books were returned again, and the form of the workbook was introduced. In 1973, the resolution of the Council of Ministers of the USSR and the Supreme Soviet of the USSR of 06.09.1973 N 656 "on labor books of workers and employees" was adopted, where it was written that the labor book is the main document on the labor activity of citizens.

In 2003 the Government adopted a Resolution of the Russian Federation dated 16.04.2003 No. 225 "On labor books" [1] and the Decision of the Ministry of labor of Russia dated 10.10.2003 No. 69 "On approval of the Instruction on filling of work record" [2], which still apply today.

Thus, the practice of keeping employment records in Russia has a century-old history.
In connection with the implementation of the national project "Digital economy", a number of regulatory legal

acts providing for the introduction of electronic labor books came into force in 2020. In particular, the Federal law of 16.12.2019 $\mathrm{N}$ 436-FZ "on amendments to the Federal law "on individual (personalized) accounting in the mandatory pension insurance system"[3], the Federal law of 16.12.2019 N 439-FZ "on amendments to the Labor code of the Russian Federation regarding the formation of information about employment in electronic form"[4], the Resolution Of the Board of the PF of the Russian Federation of 25.12.2019 N 730p "on approval of the form and format of information about the employment of a registered person, as well as the procedure for filling in the forms of specified information"[5] and others.

\section{RESEARCH METHODOLOGY}

The research applied logical, historical-legal, comparativelegal, system methods of scientific knowledge, as well as methods of analysis and synthesis.

\section{RESULTS OF THE RESEARCH}

By 2021, employees must decide what kind of work record they should keep. The following arguments are given as advantages of maintaining electronic labor book: 
- convenient and quick access of employees to information about their work;

- minimization of erroneous, inaccurate and unreliable information about employment;

- additional opportunities for remote employment;

- reducing the cost of employers to purchase, maintain and store paper labor books ;

- remote registration of pensions based on personal account data without additional documentary confirmation;

- use of electronic work record data to obtain public services;

- new opportunities for analytical processing of labor activity data for employers and government agencies;

- high level of data security and safety[6].

Some of these advantages of an electronic work record are rather dubious. For example, reducing the cost of employers to purchase, maintain and store paper labor books, since most employees will decide to leave the paper labor books, and the employer has a new obligation to send documents in the form of a CV-TD [7] to the FIU. In addition, the high level of data security and safety is questionable, since practice shows that in many countries such systems are hacked.

Some authors also add to the advantages of the electronic labor book the absence of future disputes over the delay in issuing the labor book [8]. It should be noted that the employer remains obliged to issue an extract from the electronic work record on the last day of work. Therefore, if it is delayed, disputes may arise about the delay in issuing an extract from the electronic labor book.

The undoubted advantage of an electronic work record is that the employer will not be able to lose it. In addition, the introduction of e-books will exclude the possibility for employees in violation of labor laws to have two labor books .

As disadvantages of electronic labor books, the authors cite the following: labor costs of personnel employees for processing additional documentation, even in electronic form, and if the employee has kept a paper workbook, then storing and maintaining paper labor books (so-called double accounting), problems of monitoring and preventing incomplete or incorrect entry of information in the electronic workbook, the possibility of falsifying an extract from the electronic workbook, as well as the security of the personal accounting system [9].

The disadvantages of the electronic work record also include the lack of technical ability to transmit and (or) receive information by exchanging electronic documents, including in connection with problems with the Internet[10].

There is a discussion in the legal literature on whether a work record is needed. Some authors believe that the work book is not necessary [11]. They provide the following arguments. The basis of occurrence of labour relations is the labour contract, and not the corresponding entry in the workbook, with the introduction of electronic personified accounting in system of compulsory pension insurance work-book lost its importance as the primary proof of work experience, in addition, it is a relic of the past and in most foreign countries, and ceased to be an institution of control by the state over the employee's work. They believe that the abolition of labor books will have a positive result, since it reduced the load on staff, reduce the number of offences in the area of illegal distribution of personal data of the employee and the employer will not be able to blackmail the employee by dismissal on disciplinary grounds, since the new employer specified grounds are not known[12].

Supporters of preserving the labor books note that if it is canceled, the employer will be forced to collect information about the employee from previous employers by requesting letters of recommendation and characteristics that are subjective, since at present the work record is an objective recommendation letter[13]. In addition, it may be difficult to prove work experience prior to 2001. According to the decision of the constitutional Court of the Russian Federation[14] the record in the labor book detects the presence of work experience, helps to prove its existence in challenging the situation where the employer did not pay insurance premiums when the fact of the employment relationship between employer and employee.

In addition, for a worker, the abolition of labor books will lead to uncertainty with fixing the base of the dismissal of an employee, the employer is the lack of guarantees for the practice employee a 2-week period from the date of submission of resignation, the risk to hire a person who has previously dismissed on disciplinary grounds [15]. Thus, the abolition of the work record will be beneficial for unscrupulous employees and unscrupulous employers. Analyzing the above arguments, you should agree with the opinion of supporters of preserving the work record.

In foreign countries, paper labor books are used only in the CIS countries. In some countries, there are documents that are passed to the employer by the employee when entering the job. In Germany, Italy, Austria and France, a work card is used. It differs from the Russian work book in that the owner can present it to the employer only at his own discretion in order to enter data on employment and dismissal [16].

There are no employment records in the United States. When applying for a job, they usually require a characteristic from the last job or a letter of recommendation.

In Spain, the equivalent of an electronic work record is the Informe de vida laboral, an official document that records the length of service in Spain. You can get it by personal request or via the Internet. The Report contains information about the work regime (in the Russian Federation, the equivalent is working with special working conditions or special experience), as well as information about the payer of insurance premiums.

Thus, the Report is a document by which an employee can control the payment of insurance premiums by the employer for him, and is also used for assigning a pension. When applying for a job, the Report is not a mandatory document provided by the employee. 
In Germany, the equivalent of Russian labor books are labor certificates (TS). For each new employer, an employee is issued a separate employment certificate. Vehicles are drawn up on a sheet of A4 paper and they are unbroken. Depending on the content of the vehicle, there may be simple and qualifying ones. A simple vehicle contains information about the employee's identity, type and duration of employment. The qualification vehicle also contains a characteristic of the employee and consists of five parts: the duration of employment at the enterprise; the content of the activity; assessment of achievements; assessment of behavior (in relation to management, employees); the reason and urgency of dismissal. In addition, in Germany, employees also have a social insurance book [17].

Thus, it is necessary to use the best foreign experience for to reforming Russian labor legislation in the field of labor books. The Spanish practice on the Report is already used in the Russian Federation as an extract from the FIU, and the German practice on labor lists can be supplemented as a separate section in the FIU statement. The only thing that should be two forms of statement from the FIU: one for the employee-full, the other for the employer-truncated. In particular, the employer does not need to provide information about the amount of insurance premiums paid for the employee by other employers.

The content of the electronic labor book includes almost the same sections as the paper one, with the exception of the section on awards and education. It seems that the eemployment record must contain information about education. At the same time, we can agree with the authors who believe that in Chapter 31 of the Labor code of the Russian Federation it is advisable to fix all forms of professional education and training (art.196-197): higher education; secondary vocational education; vocational training (retraining); advanced training; internship[18]. At the same time, all forms of professional education that the employee received must also be entered in the employment record.

The inclusion of information about an employee's employment in the electronic labor book only from 2020 is beneficial to unscrupulous employees, since their previous dismissal on disciplinary grounds will remain secret from the employer. However, information about the employee from 2001 to 2019 is available from the FIU in electronic form. In this connection it is expedient to amend the Order of the Ministry of labor of Russia "About the statement of forms of information on work activities provided to the employee by the employer, forms of providing information about the labour activities of the information resources of the Pension Fund of the Russian Federation and the procedure of their filling in" putting that in the electronic work book submitted data since 2001. It is also necessary to work on digitizing information about the employee's employment before 2001 .

There are organizational problems when switching to electronic labor books .

First, the form of entry in the employment labor book when issuing an electronic employment labor book has not been approved. Various options are offered such as:" an application has been Submitted for the employer to provide information about employment in accordance with article 66.1 of the labor code of the Russian Federation "or" an electronic work record was issued " [19]. It is necessary in the resolution of the Government of the Russian Federation "On labor books" to make 15.1, as follows: "When selecting an employee e-labor book, work book paper makes a relevant entry," and also the Instruction on filling of labor books to make a claim 6.3 as follows: "Upon application by the employee to provide the employer information about work activities in accordance with article 66.1 of the Labour code, in the paper work book the entry "Submitted a statement to provide the employer information about work activities in accordance with article 66.1 of the Labour code"'".

In addition, the regulatory legal acts do not specify the period during which the employer is obliged to issue an employee who has chosen an electronic labor book with his / her paper labor book. At first, the Ministry of labor recommended issuing a paper labor book immediately[20], but later changed its opinion and suggested following article 62 of the Labor code of the Russian Federation on the three-day period[21]. The latter position of the Ministry of labor is more reasonable, since when switching to an electronic labor book, a paper labor book loses its legal significance as a document for employment.

In this regard, it seems necessary to add clause 37.1 to the Decree of the Government of the Russian Federation "on labor books " as follows: "When an employee submits an application for the provision of information about employment by the employer in accordance with article 66.1 of the Labor code, a paper workbook must be issued to the employee within three days from the date of filing the application".

Secondly, the law does not specify whether an employee can change their choice regarding the form of the labor book. It appears that if the employee has chosen an electronic labor book, then no. If he chose a paper labor book, it can be up to 2021. Moreover, it should be possible for an employee who has chosen a paper labor book to switch to an electronic labor book at any time (not just until 2021). It is necessary to make changes to the Instructions for filling out labor books, indicating that if an employee has chosen a paper labor book, he can switch to an electronic labor book at any time by writing an appropriate application.

\section{CONCLUSIONS}

After analyzing the legislative, empirical and scientific material on labor books, we can come to the following conclusions.

1. In Russia, there is a long-term experience of maintaining labor books, which has shown itself on the positive side. In this regard, there is no reason to refuse the institution of labor books in the Russian Federation. 
2. In the digital economy, there is a need to switch to electronic labor books. However, there is a question about the format of such a transition, since many of the information in electronic labor books is already provided to the FIU as part of mandatory pension insurance. In this regard, there may be discrepancies in the information in these databases. Therefore, it seems appropriate to maintain a single FIU information base that includes both information in the framework of mandatory pension insurance and the employee's employment. At the same time, it is necessary to provide the employee with a full statement, including all information about the employee's insurance payments, and a limited one-only about the employee's work. And the employer should only provide a limited amount.

3. Taking into account foreign experience in providing information about employment, the experience of Spain, which contains a single information base that includes both information in the framework of mandatory pension insurance and the employee's employment, and provides quick access to information about the employee's employment, looks preferable.

4. It seems unreasonable to include information about the employee's employment in the electronic labor book only from 2020. It is necessary to enter information about the work since 2001, especially since the FIU has this information, and also work on digitizing information about the employee's work until 2001.

5. Seems unwarranted exception to the electronic workbook section education of the employee, because the information from this section is required as the employer offer the employee work in the reduction of staff, changes in organizational conditions of work and employment services for unemployed while searching for a suitable job. 6. There are organizational problems when switching to electronic labor books. You must approve the form of entry in the paper labor book when issuing electronic labor book, to set the period during which the employer is obliged to provide selected electronic labor book to the employee his labor book paper, to provide an opportunity for the employee who chose a paper workbook any time (not just to 2021) to move to electronic labor book, having written the corresponding application.

\section{REFERENCES}

[1] Resolution of the Government of the Russian Federation of 16.04.2003 N 225 "On labor books" / / Sobranie zakonodatel'stva of the Russian Federation. 2003. - N 16. Article 1539.

[2] Resolution of the Ministry of labor of Russia of 10.10.2003 N 69 "On approval of Instructions for filling in labor books " / / Rossiyskaya Gazeta. N 235. 19.11.2003/
[3] 3. Federal law of 16.12.2019 N 436-FZ "on amendments to the Federal law "On individual (personalized) accounting in the mandatory pension insurance system " // Sobranie zakonodatel'stva of the Russian Federation. 2019. N 51 (part I). St. 7488

[4] Federal law of 16.12.2019 N 439-FZ "On amendments to the Labor code of the Russian Federation in terms of forming information about labor activity in electronic form" / / Sobranie zakonodatel'stva of the Russian Federation. 2019. N 51 (part I). Article 7491

[5] Resolution of The Board of the PF of the Russian Federation of 25.12.2019 N 730p "On approval of the form and format of information about the employment of a registered person, as well as the procedure for filling in the forms of specified information" / / Official Internet portal of legal information http://www.pravo.gov.ru, 24.01.2020

[6] FIU information About the introduction of an electronic work record from 2020 // http://www.pfrf.ru/ etk

[7] Resolution of the Board of the FIU dated December 25, 2019 No. 730p. / / Official Internet portal of legal information http://www.pravo.gov.ru, 24.01.2020

[8] A.V Prisekin., M.A. Lebedev Some problems of maintaining an electronic work record / / Zakon i pravo. - 2020. - No. 1. - P. 65

[9] E. Poluboyarov 5 main risks of accelerated transition to electronic labor books //https:/www.garant.ru/ia/opinion/author/poluboyarov/ 1281989/

[10] A.M. Kurennoj, I.A.Kostyan Digital economy and labor relations (problems of introduction of electronic document management) / / M. Statut, 2019 (from the information Bank "Legal press") / / SPS ConsultantPlus

[11] V.I. Mironov To date, the situation is such that the Labor code is unlikely to radically change the situation with the regulation of labor relations // Personnel Management. 2006, N 23 P.. 54-58.

[12] L.B.Setdarova Electronic work book: realities and prospects / / Legal research. 2013. No 2. P. 74.

[13] I.Delyagin The fate of the work book / / EzhLawyer. 2011. No 35. P. 103

[14] Resolution of the constitutional Court of the Russian Federation No. 9-P of 10.07.2007 // Sobranie 
zakonodatel'stva of the Russian Federation 2007. No 29. P. 3744

[15] I.A.Filipova Labor books and the consequences of their possible cancellation / / Bulletin of the Nizhny Novgorod University. N. I. Lobachevsky . - 2012. - No. 3 (1). - P. 299.

[16] YU.A.Mel'nichuk, A.Matrosova Employment history: history, policy and international experience // the New generation. 2014. No. 7. Pp. 183-188 .

[17] I. Durakova Germany works with labor certificates / / HR officer. HR management", 2007, N 2 P. 60-62.

[18] Petrov A Y, Lada A S Professional Education and Training of Employees: On the New Doctrine of the Institute of Labor Law // International Scientific Conference "Far East Con" (ISCFEC 2020) // Published by Atlantis Press SARL Advances in Economics, Business and Management Research, volume 128. P. 2358-2362-.

[19] Electronic labor books : what to do for an employer in 2020 / / Consultant Plus

[20] Letter of the Ministry of labor dated 12.02.2020 №14-2 / V-150 "on the application of labor legislation" / / SPS Garant

[21] Letter of the Ministry of labor dated 13.03.2020 №14-2/B-260 